\title{
GRAPEVINE VIRUS DISEASES: ECONOMIC IMPACT AND CURRENT ADVANCES IN VIRAL PROSPECTION AND MANAGEMENT ${ }^{1}$
}

\author{
MARCOS FERNANDO BASSO², THOR VINÍCIUS MARTINS FAJARDO, \\ PASQUALE SALDARELLI ${ }^{4}$
}

\begin{abstract}
Grapevine (Vitis spp.) is a major vegetative propagated fruit crop with high socioeconomic importance worldwide. It is susceptible to several graft-transmitted agents that cause several diseases and substantial crop losses, reducing fruit quality and plant vigor, and shorten the longevity of vines. The vegetative propagation and frequent exchanges of propagative material among countries contribute to spread these pathogens, favoring the emergence of complex diseases. Its perennial life cycle further accelerates the mixing and introduction of several viral agents into a single plant. Currently, approximately 65 viruses belonging to different families have been reported infecting grapevines, but not all cause economically relevant diseases. The grapevine leafroll, rugose wood complex, leaf degeneration and fleck diseases are the four main disorders having worldwide economic importance. In addition, new viral species and strains have been identified and associated with economically important constraints to grape production. In Brazilian vineyards, eighteen viruses, three viroids and two virus-like diseases had already their occurrence reported and were molecularly characterized. Here, we review the current knowledge of these viruses, report advances in their diagnosis and prospection of new species, and give indications about the management of the associated grapevine diseases. Index terms: Vegetative propagation, plant viruses, crop losses, berry quality, next-generation sequencing.

\section{VIROSES EM VIDEIRAS: \\ IMPACTO ECONÔMICO E RECENTES AVANÇOS NA PROSPECÇÃO DE VÍRUS E MANEJO DAS DOENÇAS DE ORIGEM VIRAL}

RESUMO-A videira (Vitis spp.) é propagada vegetativamente e considerada uma das principais culturas frutíferas por sua importância socioeconômica mundial. Ela é suscetível a vários agentes transmitidos por meio da enxertia, os quais causam diversas doenças e significativas perdas na produtividade e produção, redução na qualidade dos frutos, no vigor da planta e na longevidade dos vinhedos. A propagação vegetativa e o frequente intercâmbio de material propagativo entre países contribuem para a disseminação destes patógenos, favorecendo a emergência de doenças complexas. Seu ciclo de vida perene acelera ainda mais a mistura e a introdução de vários agentes virais em uma mesma planta. Atualmente, aproximadamente 65 vírus pertencentes a diferentes famílias foram reportados infectando videiras, embora nem todos causem doenças economicamente relevantes. As viroses do enrolamento da folha, complexo do lenho rugoso, degenerescência e mancha-das-nervuras da videira são as quatro principais desordens que têm importância econômica mundial. Além disso, novas espécies e estirpes virais foram identificadas e associadas a limitações economicamente importantes para a produção de uvas. Em vinhedos brasileiros, dezoito espécies virais, três viroides e duas doenças semelhantes a viroses já tiveram sua ocorrência reportada e foram molecularmente caracterizados. Aqui, nós revisamos o conhecimento atual dessas viroses, os recentes avanços na diagnose e prospecção viral, e fornecemos recomentações sobre o manejo das viroses da videira.

Termos para indexação: Propagação vegetativa, vírus de plantas, redução da produtividade e produção, qualidade das bagas, sequenciamento de nova geração.

\footnotetext{
1(Paper 284-15). Received december 15, 2015. Accepted June 21, 2016.

${ }^{2}$ Postdoctoral position; Plant Biotechnology; Embrapa Agroenergia, Brasília, DF, 70770-901, Brazil. E-mail: marcosbiotec@gmail.com ${ }^{3}$ Researcher; Embrapa Uva e Vinho, Rua Livramento, 515, Bento Gonçalves, RS, 95701-008, Brazil. E-mail: thor.fajardo@embrapa.br ${ }^{4}$ Researcher; Istituto per la Protezione Sostenibile delle Piante (IPSP), CNR, Via Amendola 165/A, 70126, Bari, Italy. E-mail: pasquale. saldarelli@ipsp.cnr.it
} 


\section{INTRODUCTION}

Grapevine (Vitis spp.) is a major crop having a worldwide high socioeconomic importance (CAMARGO et al., 2011; RUIZ, 2011). It is susceptible to several graft-transmitted agents that cause or are associated with several diseases, whose etiology is yet unknown (MALIOGKA et al., 2015a; MARTELLI, 2014). Vegetative propagation and frequent exchanges of propagative material have contributed to worldwide spread of these pathogens, favoring the emergence of complex diseases (AL RWAHNIH et al., 2009; BASSO et al., 2014). Moreover, its perennial life cycle accelerated the mixing and introduction of several viral agents into a single plant (BARBA et al., 2015; MARTELLI, 2014). Grapevine viral diseases cause substantial crop losses, reduce plant vigor and shorten the longevity of vines. In addition, they also affect technological characteristics due to a delayed ripening and reduced quality of berries, with impact on sugar content, pigments and increased acidity of wines (BASSO et al., 2010c; BARBA et al., 2015; NASCIMENTO et al., 2015).

Currently, approximately 65 viruses, eight viroids and four satellite RNAs belonging to different families have been reported infecting grapevines (CHIUMENTI et al., 2016; FIORE, 2015; MALIOGKA et al., 2015a; MARTELLI, 2014) (Table 1). Grapevine leafroll, rugose wood complex, leaf degeneration and fleck disease are the four main disorders having a worldwide economic importance (ANDRET-LINK et al., 2004; MARTELLI, 2014; NAIDU et al., 2015). Grapevine viruses associated with these diseases have a RNA genome. Recently, DNA viral agents have been identified, such as a geminivirus associated with Red blotch disease in the USA (AL RWAHNIH et al., 2013b; KRENZ et al., 2012 and 2014; POOJARI et al., 2013), two badnaviruses associated with Grapevine vein-clearing and vine decline syndrome in the USA (ZHANG et al., 2011) and with Roditis leaf discoloration disease in Greece (MALIOGKA et al., 2015b), and a unclassified virus associated with fruit tree decline syndrome in the Brazilian orchards and vineyards (BASSO et al., 2015).

Disease expression may be influenced by environmental factors, grapevine cultivar, rootstock, viral isolate or strain, intrinsic agronomic conditions or association with others pathogens or viruses (MALIOGKA et al., 2015a). All these pathogens are disseminated across long distances by vegetative propagation (MARTELLI, 2014) whereas local plant-to-plant transmission is operated by insect, mite or nematode vectors (MALIOGKA et al., 2015a; MARTELLI, 2014) (Table 1).

The grapevine viruses control, as well as for other plant species, is inevitably based on determining the sanitary status of the vines. Therefore besides the experience in recognizing the symptoms caused by these pathogens, the availability of efficient detection techniques is important. Recent advances in molecular biology tools to study the viral population present in vineyards, allowed the efficient detection, identification and prospection of known or new viral species and strains (AL RWAHNIH et al., 2015; BURGER; MAREE, 2015; ROOSSINCK et al., 2015). Using next-generation sequencing technologies (NGS) (AL RWAHNIH et al., 2015) and rolling-circle amplification (RCA) strategies (INOUE-NAGATA et al., 2004) have enhanced the diagnosis tools and knowledge of grapevine virome (AL RWAHNIH et al., 2013b; BASSO et al., 2015; GIAMPETRUZZI et al., 2012; MALIOGKA et al., 2015b). In Brazilian vineyards, eighteen viruses, three viroids, two virus-like diseases and some phytoplasmas have been already reported and were molecularly characterized (BASSO et al., 2014) (Table 2 and 3 ).

This research presents the current state of knowledge of these economically important viruses in grape-growing countries, including Brazil, and report advances in their diagnosis and prospection, and give indications about the management of the associated diseases.

\section{DAMAGES AND ECONOMIC IMPACT OF GRAPEVINE V IRUS DISEASES}

Viruses and subviral agents are active only after being introduced into living cell, in which they replicate as parasites using the biological systems of the host cell and changing several physiological functions (FIORE, 2015). Viral disease effects in grapevines can manifest in more specific or more comprehensive forms, with variations that depend on the viral species or strains, grapevine cultivar and agronomic or climatic conditions. Infected plants exhibit changes in genes expression profile, carbohydrate metabolism and hormonal balances, decrease in photosynthetic potential, increase in respiration rate, interference in electron transport activity of photosystem I and II, reduction of the chlorophyll levels and soluble sugar accumulation in the leaves and deficiency in translocation of these sugars to sink tissues or grape berries (BASSO et al., 2010c; NAIDU et al., 2015). 
In addition, there is up or down regulation of several genes involved in critical metabolic pathways, such as biosynthesis of primary or secondary metabolites, signaling, proteins associated with senescence (proteases, lipases, proteins involved in nutrient remobilization, transcription factors, proteins related to translation and antioxidant enzymes), defense-related genes to biotic or abiotic stress, and vegetative development of the host plants (ESPINOZA et al., 2007; VEGA et al., 2011). These stresses have effects in berry quality because of irregular ripening and affect plant growth resulting in a delay of sprouting, reduced tolerance to stresses and even death of the chronically infected plants (CRETAZZO et al., 2010 and 2013; GIRIBALDI et al., 2011; NASCIMENTO et al., 2015; VEGA et al., 2011). Grapes harvested from infected grapevines show reduced total soluble solid content (from 3 to $5{ }^{\circ} \mathrm{Brix}$ ), color intensity of red-berried cultivars of up to $35 \%$, total polyphenol content of up to $38 \%$, biosynthesis of tannins, flavonoids, anthocyanins, polyamines, aromatic compounds and other metabolites, and increase in titratable acidity of the must (ALABI et al., 2016; BASSO et al., 2010c; GUTHA et al., 2010; NAIDU et al., 2015). A recent study in the USA estimated that the economic impact of grapevine leafroll disease on the profit of grape businesses range from $\$ 25,000$ to $\$ 40,000$ per hectare for vineyards with a 25-year lifespan (ATALLAH et al., 2012).

\section{MAJOR GRAPEVINE VIRAL DISEASES}

Grapevine leafroll disease (GLRD): GLRD is the most economically damaging and widespread viral disease of grapevine throughout the world (ALABI et al., 2016; ALMEIDA et al., 2013; ATALLAH et al., 2012; NAIDU et al., 2014 and 2015). It can cause up to $40 \%$ yield losses (NAIDU et al., 2014). Several viral species designated Grapevine leafroll-associated viruses belonging to the family Closteroviridae (genus Ampelovirus, Closterovirus and Velarivirus) are related to GLRD, which can occur alone or as viral complex (MAREE et al., 2013; MARTELLI et al., 2012). The GLRaV-2 and -3 are the most prevalent and widely spread (MAREE et al., 2013; MARTELLI, 2014). The first symptoms in adult plants appear on mature leaves, always from the base of the canes, progressively moving upward to younger leaves, which is more pronounced at the end of the growing season, while young sproutings of grafted-vine cuttings are commonly asymptomatic (NAIDU et al., 2014; TSAI et al.,
2012). The $V$. vinifera exhibit conspicuous symptoms, while $V$. labrusca, hybrids and rootstocks are often asymptomatic or the symptoms may be mild (BASSO et al., 2014). Typical symptoms are leaf reddening (in red-berried cultivars) or yellowing (in white-berried cultivars) with coriaceous texture while veins remain green and leaf edges roll downward (GLRaV-1 to -3). Some GLRaV-2 strains are cause of graft incompatibility (NAIDU et al., 2014) (Figure 1A and B). Asymptomatic leaves or milder symptoms can also be observed (GLRaV-4 and -7) (MALIOGKA et al., 2015a). Several soft scale and mealybug species are efficient vectors of the ampeloviruses in a semi-persistent transmission manner (Table 3) (LE MAGUET et al., 2012; TSAI et al., 2010 and 2012). However, no vector has been identified for GLRaV-2 and -7 .

\section{Grapevine rugose wood disease (GRWD):}

GRWD is a complex disease of grapevines in several growing regions (MALIOGKA et al., 2015a; MARTELLI, 2014). Four distinct syndromes are GRWD-associated: rupestris stem pitting, kober stem grooving, LN33 stem grooving and corky bark, which are often latent or mild symptoms in ungrafted vines and strongly evident in grapevine-grafted $V$. vinifera (MARTELLI, 2014). Associated agents are Grapevine rupestris stem pitting-associated virus (GRSPaV; genus Foveavirus) and Grapevine viruses $A, B$, and $D$ (genus Vitivirus), all belonging to the Betaflexiviridae family (KING et al., 2012; MARTELLI et al., 2007). Typical symptoms in $V$. vinifera are characterized by alterations of the plant woody cylinder consisting in pitting and grooving of the region underneath the bark, which affect water and nutrient flow, cause reddening of the entire leaf blade, induce formation of corked bark in the internode region, provoke graft incompatibility, delayed budding, grapevine decline and eventually, plant death (MALIOGKA et al., 2015a; ROSA et al., 2011). In contrast, in $V$. labrusca a swelling of internodes in the branches of the year and tissue longitudinal splitting are observed (Figure 1C) (NICKEL et al., 2002). Stem pitting is observed in susceptible rootstocks such as Paulsen $1103(\mathrm{~V}$. berlandieri $\mathrm{x}$ V.rupestris) (Figure 1D) (MALIOGKA et al., 2015a; ROSA et al., 2011). GRWD-associated viruses are semi-persistently vectored by several mealybugs and soft scale insects (Table 3), while GRSPaV has no known insect vector and is not mechanically transmitted to herbaceous hosts (KING et al., 2012; LE MAGUET et al., 2012; MARTELLI, 2014). GLRD and GRWD are the two most economically important disease complexes in 
Brazilian vineyards (BASSO et al., 2014).

\section{Grapevine fanleaf degeneration disease} (GFDD): GFDD is considered the most important grapevine disease in Europe and North American vineyards, which occurs in almost all grapevine cultivated regions (ANDRET-LINK et al., 2004; MALIOGKA et al., 2015a). Its main etiological agent is Grapevine fanleaf virus (genus Nepovirus) belonging to the Secoviridae family (MARTELLI, 2014). The GFDD is endemic to areas where its soil-borne nematode vector is present (VILLATE et al., 2008). Typical symptoms are leaf distortion, yellow mosaic close to primary veins, bright yellow vein banding on leaves, widely open petiolar sinuses, double nodes, short and malformed internodes (Figure 1E). In general, foliar symptoms appear at the beginning of the growing season. In Brazilian vineyards, GFLV has been reported, but apparently GFDD is not economically important (FAJARDO et al., 2000; RADAELLI et al., 2009). Probably the occurrence of specific nematode vectors is limited or grapevine cultivated soils do not support the survival of these vectors in Brazilian conditions. GFLV is semi-persistently vectored by both juvenile stages and adults of the ectoparasitic nematodes Xiphinema index and $X$. italiae (DEMANGEAT et al., 2010; COHN et al., 1970).

Grapevine fleck disease (GFkD): GFkD is reported from all viticultural countries in the world (MARTELLI, 2014). The associated virus is Grapevine fleck virus (GFkV) belonging to the Tymoviridae family, which is a non-mechanically transmissible virus associated with fleck symptoms (SABANADZOVIC et al., 2000 and 2001). Several GFkV-infected $V$. vinifera and rootstock cultivars are symptomless. GFkV causes latent infections in $V$. vinifera cultivars and induces typical foliar symptoms of vein clearing, leaf deformation and reduction of the vegetative growth in the sensitive indicator $V$. rupestris St. George (FAJARDO et al., 2012; MARTELLI, 2014) (Figure 1F). GFkV has no known insect vector. In Brazilian vineyards, GFkD has been reported, but its importance and damage were not specifically evaluated (BASSO et al., 2014; FAJARDO et al., 2012).

\section{New emerging diseases of grapevine}

Decline of Syrah grapevines: first observed in France (RENAULT-SPILMONT et al., 2004), it was subsequently reported in California vineyards (BATTANY et al., 2004), and has been associated with several viral species. Typical disease symptoms appear in older grapevines, which include leaf reddening and scorching, swelling of the graft union, superficial cracking and pitting of the woody tissue and stem necrosis (AL RWAHNIH et al., 2009). A virus, Grapevine Syrah virus-1, was discovered in symptomatic grapevines in California (USA) (AL RWAHNIH et al., 2009) that is widely spread worldwide (ENGEL et al., 2010; FAJARDO et al., 2015c; GLASA et al., 2015) but its association with the disease was not clearly demonstrated. Its presence in leafhoppers (vector for marafiviruses) collected from diseased vines has been reported (AL RWAHNIH et al., 2009).

Red blotch disease: first reported in California (USA) in 2008 (CALVI, 2011). In redberried grapevine cultivars, foliar symptoms consist of red blotches of the basal leaves early in the season that can expand and coalesce across most of the leaf blade later in the season and extend to middle leaves of the shoots. In contrast, in white-berried cultivars symptoms are less conspicuous and generally involve irregular chlorotic areas that may become necrotic late in the season (SUDARSHANA et al., 2015). Diseased vines show reduced total soluble solids, fruit quality and a delayed ripening. The causal agent is the Grapevine red blotch-associated virus (GRBaV) which was recently shown to induce symptoms when inoculated in grapevine as cloned DNA (AL RWAHNIH et al., 2013b; FUCHS et al., 2015; POOJARI et al., 2013). GRBaV was confirmed infecting free-living vines (Vitis spp.), two of which were $V$. californica $\times$ V vinifera hybrids, in a proximal field of cultivated grapevines (PERRY et al., 2016). The leafhopper Erythroneura zic-zac Walsh (POOJARI et al., 2013) was shown to transmit $\mathrm{GRBaV}$ but its role as vector is uncertain.

Vein-clearing and vine decline syndrome: emerged in 2004, from a commercial vineyard in Missouri (USA) (QIU et al., 2007). Grapevine vein clearing virus (GVCV) was found associated with vein-clearing symptom, shortening of the internodes, crinkled leaves, misshapen and smaller grape berries, with irregular shape and abnormal texture (GUO et al., 2014; ZHANG et al., 2011). GVCV has no known insect vector and its economic importance is not clearly defined. However it should be noted that some badnaviruses are transmitted by pseudococcid mealybugs (MARTELLI; SALDARELLI, 2015).

\section{Chlorotic mottling and leaf deformation:} reported in grapevine cv. Pinot gris in Trentino Alto Adige vineyards (Italy) since 2003 (GIAMPETRUZZI 
et al., 2012), to which a new RNA virus, Grapevine Pinot gris virus (GPGV), was found associated. The virus has been reported infecting several varieties in many European Countries (BEUVE et al., 2015; GAZEL et al., 2016; GLASA et al., 2014; MARTELLI, 2014; SALDARELLI et al., 2015) and recently in Californian grapevines, USA (AL RWAHNIH et al., 2009; RIEGER, 2015) and China (FAN et al., 2016). Its association with the disease is not clearly established due to the existence of different viral strains and diverse cultivars susceptibility (SALDARELLI et al., 2015). However, the associated disease has an important economic impact since it affects plant vigor and reduces the yield. The eriophyid mite Colomerus vitis is a vector of GPGV (MALAGNINI et al., 2016) and the herbaceous plants Silene latifolia subsp. alba (Mill.) (bladder campion) and Chenopodium album L. (white goosefoot) can be considered as a reservoir of the GPGV (GUALANDRI et al., 2016).

Roditis leaf discoloration disease: first reported in Greek vineyards in the 1980s (RUMBOS; AVGELIS, 1989). Grapevine roditis leaf discoloration-associated virus (GRLDaV) was recently found associated with typical symptoms of yellow and/or reddish discolorations and deformations of the young leaves, while grape berries are reduced in number and size, and have lower sugar content (MALIOGKA et al., 2015b). Recently the virus was also discovered in symptomless vines in Apulia, Italy (GIAMPETRUZZI et al., 2015). Since natural disease spreading was observed and considering that the disease agent has been identified as a badnavirus, it is plausible to hypothesize that a vector, possibly a pseudococcid mealybug, be responsible for transmission (MARTELLI; SALDARELLI, 2015).

Fruit tree decline syndrome: a complex disease that could be caused by several pathogens in orchards and vineyards. Recently, a new viral agent, Temperate fruit decay-associated virus (TFDaV), has been identified in Brazil infecting apple and pear trees and grapevine and probably it could be associated with fruit tree decay symptoms (BASSO et al., 2015). In addition, different viruses (hitherto considered absent in Brazil), viroids and phytoplasmas [belonging to ribosomal groups 16SrI (subgroup B) and 16SrIII (subgroup J or F)], were recently reported in Brazilian vineyards and their spread and economic importance are being investigated (CATARINO et al., 2015; EIRAS et al., 2006; FAJARDO et al., 2015a, 2015b; 2015c; ROHR DOS SANTOS et al., 2015; NERONI, 2009) (Table 2).

\section{CURRENT ADVANCES IN DIAGNOSIS METHODS}

The application of accurate and reliable diagnosis methods has fundamental importance in programs that are intended to produce and maintain virus-free propagating material, and are crucially important to the success of any preventive and control strategies of grapevine viral diseases (MALIOGKA et al., 2015a; ROOSSINCK et al., 2015). Virus diagnosis has evolved over the years, moving from the monitoring of grapevine sanitary status, biological indexing, transmission electron microscopy (TEM), serological ELISA-based methods, probe-based nucleic acid hybridization, PCR-based molecular methods, to high-throughput sequencing technology (AL RWAHNIH et al., 2015; BURGER; MAREE, 2015; MALIOGKA et al., 2015a).

All these methods present important limitations and several advantages (BASSO et al., 2014). The biological indexing is time-consuming, limited for inconspicuous symptoms and latent infections, while TEM and micro- or macroarrays are low efficient or onerous (ABDULLAHI et al., 2011; MALIOGKA et al., 2015a; TERLIZZI et al., 2010; THOMPSON et al., 2012). ELISA- or PCR-based methods are limited to viruses for which antibodies or virus-specific nucleotide sequences are available, while being are more rapid and efficient (BASSO et al., 2010b; FAJARDO et al., 2007a; MALIOGKA et al., 2015a). Conventional RT-PCR or real-time RT$\mathrm{PCR}$ and its variations are currently the most used methods in routine assays. Immunocapture RT-PCR allows greater sensitivity and specificity, while RTqPCR allows single or multiplex viral detection, viral load quantification, differentiation of viral variants with high sensitivity, specificity and reproducibility (AL RWAHNIH et al., 2012; BESTER et al., 2012; DUBIELA et al., 2013; KUMAR et al., 2015; LÓPEZ-FABUEL et al., 2013; OSMAN et al., 2013). RCA method also has been successfully used in grapevine virus amplification and detection (BASSO et al., 2015; KRENZ et al., 2012). Specific protocols for nucleic acids isolation and purification from grapevine tissues have been strongly recommended to improve sensitivity (AKKURT, 2012; PICCOLO et al., 2012; XIAO et al., 2015). In addition, the plant development stage and specific tissues in which the virus reaches higher concentration should be observed to perform accurate and sensitive diagnostic tests (BASSO et al., 2010a; BEUVE et al., 2007).

Finally, NGS technologies combined with advanced bioinformatics tools has currently revolutionized the research involving grapevine 
viruses (BARBA et al., 2014; BURGER; MAREE, 2015; ROOSSINCK et al., 2015). Several metagenomics studies were developed aiming to know the virome and causal agents of economically important grapevine diseases (AL RWAHNIH et al., 2009, 2013b and 2015; COETZEE et al., 2010; FAJARDO et al., 2015c; GIAMPETRUZZI et al., 2012; JO et al., 2015; POOJARI et al., 2013; ZHANG et al., 2011). In addition, several new viral species or strains of known viruses, mycoviruses, viroids and phytoplasmas were identified using NGS of total RNAs, siRNAs or dsRNAs isolated from specific tissues. However, the main current limitation of NGS-based approaches is high cost per sample sequenced. It is believed that in the near future costs may become more accessible. In contrast, NGS is a powerful technology that allows detection and discovery of viruses without any prior knowledge of their genome (BURGER; MAREE, 2015; ROOSSINCK et al., 2015).

\section{ADVANCES IN MANAGEMENT STRATEGIES}

The good health status of propagative material (cuttings, grafts, buds, rooted cuttings and grafted plants) is the main prophylactic measure to mitigate impact of virus diseases (OLIVER; FUCHS, 2011). The production and use of certified virustested propagative material reduce the inoculum potential, mainly in areas where vectors are present (MARTELLI, 2014). The establishment of vineyards in vector-free (e.g. nematodes) areas reduces local and long-distance dispersal of viruses (LAIMER et al., 2009; VILLATE et al., 2008). Measures such as rouging of symptomatic grapevines and possibly adjacent plants (and removing any remaining roots), chemical or biological control or management of insect- or nematode-vector, and cross-protection and conventional or transgenic grapevines tolerant or resistant to viruses or nematode-vector (ALMEIDA et al., 2013; ATALLAH et al., 2012; BELL et al., 2009; FUCHS et al., 2007; GAMBINO et al., 2010; KOMAR et al., 2008; OLIVER; FUCHS, 2011) are possible strategies for viral disease management. The nematode chemical control is often inefficient, environmentally improper and harmful to humans, while transgenic plants may represent a possible choice (LAIMER et al., 2009; MALIOGKA et al., 2015a).

siRNA-mediated engineered resistance or expression of artificial microRNAs (amiRNA) has been a powerful tool, but is actually limited to experimental cultivars or model plant (LAIMER et al., 2009; OLIVER; FUCHS, 2011; ROUMI et al., 2012). Sources of genetic resistance to grapevine viruses are not available. In contrast, a major genetic resistance locus to $X$. index was recently reported from grapevine (HWANG et al., 2010; XU et al., 2008).

The main sanitation techniques to eliminate grapevine viruses are thermotherapy in vivo or in vitro (KRIZAN et al., 2009; PANATTONI; TRIOLO, 2010), chemotherapy (LUVISI et al., 2011; SKIADA et al., 2013), meristem and shoot tip culture (MALIOGKA et al., 2009), somatic embryogenesis (BORROTO-FERNANDEZ et al., 2009; GAMBINO et al., 2011), electrotherapy and cryotherapy (BAYATI et al., 2011; WANG et al., 2008). However, the main limitation of the electro- and cryotherapy is the low efficiency and possible induction of host genetic changes (BARANEK et al., 2009). A higher efficiency in obtain virus-free grapevines was achieved by thermo- or chemotherapy associated with meristem and shoot tip culture. 
TABLE 1- Viruses, viroids and satellite RNAs currently reported infecting grapevines (Vitis spp.) worldwide and its insect or nematode vectors.

\begin{tabular}{|c|c|c|c|}
\hline Family & Genus & Viral species & Vector \\
\hline Alphaflexiviridae & Potexvirus & Potato virus $X(\mathrm{PVX})$ & Unknown \\
\hline \multirow{8}{*}{ Betaflexiviridae } & Foveavirus & $\begin{array}{l}\text { Grapevine rupestris stem pitting-associated virus } \\
(\mathrm{GRSPaV})^{+}\end{array}$ & Unknown \\
\hline & \multirow{2}{*}{ Trichovirus } & \multirow{2}{*}{$\begin{array}{l}\text { Grapevine berry inner necrosis virus (GINV) } \\
\text { Grapevine Pinot gris virus (GPGV) }\end{array}$} & Mites \\
\hline & & & Mites \\
\hline & \multirow{5}{*}{ Vitivirus } & Grapevine virus $A(\mathrm{GVA})^{+}$ & $\begin{array}{l}\text { Mealybugs and } \\
\text { soft scales }\end{array}$ \\
\hline & & Grapevine virus $B(\mathrm{GVB})^{+}$ & Mealybugs \\
\hline & & Grapevine virus $D(\mathrm{GVD})^{+}$ & Unknown \\
\hline & & Grapevine virus E (GVE) & Mealybugs \\
\hline & & Grapevine virus F (GVF) & Unknown \\
\hline \multirow{4}{*}{ Bromoviridae } & Alfamovirus & Alfalfa mosaic virus (AMV) & Aphids \\
\hline & Cucumovirus & Cucumber mosaic virus (CMV) & Aphids \\
\hline & \multirow{2}{*}{ Ilarvirus } & Grapevine line pattern virus (GLPV) & Unknown \\
\hline & & Grapevine angular mosaic virus (GAMoV) & Unknown \\
\hline Bunyaviridae & Tospovirus & Tomato spotted wilt virus (TSWV) & Thrips \\
\hline \multirow{5}{*}{ Closteroviridae } & Closterovirus & Grapevine leafroll-associated virus $2(\mathrm{GLRaV}-2)^{+}$ & Unknown \\
\hline & \multirow{2}{*}{$\begin{array}{l}\text { Ampelovirus } \\
\text { (Subgroup I) }\end{array}$} & Grapevine leafroll-associated virus $1(\mathrm{GLRaV}-1)^{+}$ & $\begin{array}{l}\text { Mealybugs and } \\
\text { soft scales }\end{array}$ \\
\hline & & Grapevine leafroll-associated virus $3(\mathrm{GLRaV}-3)^{+}$ & $\begin{array}{l}\text { Mealybugs and } \\
\text { soft scales }\end{array}$ \\
\hline & $\begin{array}{l}\text { Ampelovirus } \\
\text { (Subgroup II) }\end{array}$ & $\begin{array}{l}\text { Grapevine leafroll-associated virus } 4(\mathrm{GLRaV}-4)^{+} \\
\left(\text {strain } 5^{+}, 6^{+}=\mathrm{De}, 9, \mathrm{Car}, \mathrm{Pr}\right)\end{array}$ & $\begin{array}{l}\text { Mealybugs and } \\
\text { soft scales }\end{array}$ \\
\hline & Velarivirus & Grapevine leafroll-associated virus 7 (GLRaV-7) & Unknown \\
\hline \multirow[b]{2}{*}{ Caulimoviridae } & \multirow[b]{2}{*}{ Badnavirus } & ${\text { Grapevine vein clearing virus }(\mathrm{GVCV})^{+}}^{+}$ & Unknown \\
\hline & & $\begin{array}{l}\text { Grapevine roditis leaf discoloration-associated virus } \\
\text { (GRLDaV) }\end{array}$ & Unknown \\
\hline Geminiviridae & und & $\begin{array}{l}\text { Grapevine red blotch-associated virus }(\mathrm{GRBaV}) \\
\text { synonym: Grapevine cabernet franc-associated virus } \\
(\mathrm{GCFaV}) \text { and Grapevine redleaf-associated virus } \\
(\mathrm{GRLaV})\end{array}$ & Leafhopper \\
\hline
\end{tabular}


continuation...

TABLE 1 - Viruses, viroids and satellite RNAs currently reported infecting grapevines (Vitis spp.) worldwide and its insect or nematode vectors.

\begin{tabular}{|c|c|c|c|}
\hline Potyviridae & Potyvirus & Bean common mosaic virus (BCMV) & Aphids \\
\hline & Fabavirus & Broad bean wilt virus (BBWV) & Aphids \\
\hline \multirow{16}{*}{ Secoviridae } & \multirow{4}{*}{$\begin{array}{l}\text { Nepovirus } \\
\text { (Subgroup A) }\end{array}$} & Arabis mosaic virus (ArMV) & Nematode \\
\hline & & ${\text { Grapevine fanleaf virus }(\mathrm{GFLV})^{+}}^{+}$ & Nematode \\
\hline & & Raspberry ringspot virus (RpRSV) & Nematode \\
\hline & & Tobacco ringspot virus (TRSV) & Nematode \\
\hline & \multirow{3}{*}{$\begin{array}{l}\text { Nepovirus } \\
\text { (Subgroup B) }\end{array}$} & Tomato black ring virus (TBRV) & Nematode \\
\hline & & Artichoke Italian latent virus (AILV) & Unknown \\
\hline & & Grapevine chrome mosaic virus (GCMV) & Unknown \\
\hline & \multirow{6}{*}{$\begin{array}{l}\text { Nepovirus } \\
\text { (Subgroup C) }\end{array}$} & Blueberry leaf mottle virus (BBLMV) & Unknown \\
\hline & & Grapevine Tunisian ringspot virus (GTRSV) & Unknown \\
\hline & & Tomato ringspot virus (ToRSV) & Nematode \\
\hline & & Peach rosette mosaic virus (PRMV) & Nematode \\
\hline & & Cherry leaf roll virus (CLRV) & Unknown \\
\hline & & Grapevine Bulgarian latent virus (GBLV) & Unknown \\
\hline & \multirow{2}{*}{$\begin{array}{l}\text { Nepovirus } \\
\text { unclassified }\end{array}$} & Grapevine Anatolian ringspot virus (GARSV) & Unknown \\
\hline & & Grapevine deformation virus (GDefV) & Unknown \\
\hline & $\begin{array}{l}\text { Secoviridae } \\
\text { unclassified }\end{array}$ & Strawberry latent ringspot virus (SLRV) & Nematode \\
\hline \multirow{4}{*}{ Tombusviridae } & Carmovirus & Carnation mottle virus (CarMV) & Unknown \\
\hline & Necrovirus & Tobacco necrosis virus D (TNV-D) & Unknown \\
\hline & \multirow{2}{*}{ Tombusvirus } & Grapevine Algerian latent virus (GALV) & Unknown \\
\hline & & Petunia asteroid mosaic virus (PAMV) & Unknown \\
\hline \multirow[t]{4}{*}{ Tymoviridae } & \multirow[t]{2}{*}{ Maculavirus } & $\begin{array}{l}\text { Grapevine fleck virus }(\mathrm{GFkV})^{+} \\
\text {Grapevine Red Globe virus }(\mathrm{GRGV})^{+}\end{array}$ & $\begin{array}{l}\text { Unknown } \\
\text { Unknown }\end{array}$ \\
\hline & & Grapevine rupestris vein feathering virus (GRVFV) ${ }^{+}$ & Unknown \\
\hline & \multirow[t]{2}{*}{ Marafivirus } & Grapevine asteroid mosaic-associated virus (GAMaV) & Unknown \\
\hline & & Grapevine Syrah virus -1 (GSyV-1) ${ }^{+}$ & Unknown \\
\hline \multirow{2}{*}{ Virgaviridae } & \multirow{2}{*}{ Tobamovirus } & Tobacco mosaic virus (TMV) & Absent \\
\hline & & Tomato mosaic virus (ToMV) & Absent \\
\hline Reoviridae & und & 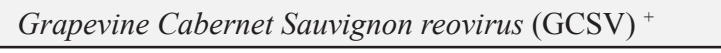 & Unknown \\
\hline und & Idaeovirus & Raspberry bushy dwarf virus (RBDV) & Unknown \\
\hline und & Sobemovirus & Sowbane mosaic virus (SoMV) & Unknown \\
\hline und & und & Grapevine Ajinashika virus (GAgV) & Unknown \\
\hline und & und & Grapevine stunt virus (GSV) & Unknown \\
\hline und & und & Grapevine labile rod-shaped virus (GLRSV) & Unknown \\
\hline und & und & Temperate fruit decay-associated virus $(\mathrm{TFDaV})^{+}$ & Unknown \\
\hline
\end{tabular}


continuation...

TABLE 1 - Viruses, viroids and satellite RNAs currently reported infecting grapevines (Vitis spp.) worldwide and its insect or nematode vectors.

\begin{tabular}{|c|c|c|c|}
\hline \multirow[t]{7}{*}{ Pospiviroidae } & \multirow[t]{5}{*}{ Apscaviroid } & Australian grapevine viroid (AGVd) & Absent \\
\hline & & Grapevine latent viroid (GLVd) & Absent \\
\hline & & Grapevine yellow speckle viroid 1 (GYSVd-1) ${ }^{+}$ & Absent \\
\hline & & Grapevine yellow speckle viroid 2 (GYSVd-2) & Absent \\
\hline & & Grapevine yellow speckle viroid 3 (GYSVd-3) & Absent \\
\hline & Hostuviroid & Hop stunt viroid $(\mathrm{HSVd})^{+}$ & Absent \\
\hline & Pospiviroid & Citrus exocortis viroid $(\mathrm{CEVd})^{+}$ & Absent \\
\hline und & und & Grapevine hammerhead viroid-like RNA (GHVd) & Absent \\
\hline \multirow[t]{4}{*}{ und } & \multirow{4}{*}{$\begin{array}{l}\text { Satellite } R N A \\
\text { (Subgroup I) }\end{array}$} & $\begin{array}{l}\text { Grapevine Bulgarian latent virus satellite RNA } \\
\text { (satGBLV) }\end{array}$ & Unknown \\
\hline & & $\begin{array}{l}\text { Satellite RNA of Grapevine fanleaf virus } \\
\text { (satGFLV-PPE) }\end{array}$ & Unknown \\
\hline & & Grapevine fanleaf virus satellite RNA (satGFLV) & Nematode \\
\hline & & RNA satellite unnamed (Al Rwahnih et al., 2013a) & Unknown \\
\hline und & und & LN33 stem grooving ${ }^{+}$ & \\
\hline und & und & Grapevine vein mosaic & \\
\hline und & und & Grapevine enation & \\
\hline und & und & Grapevine summer mottle & \\
\hline
\end{tabular}

${ }^{+}$Viruses, viroids and virus-like disease reported in Brazil infecting grapevines; und: taxonomy undetermined (ICTV Official Taxonomy, 2015). Adapted from MARTELLI (2014).

TABLE 2- Grapevine viruses and viroids reported in Brazilian vineyards and molecularly characterized.

\begin{tabular}{|c|c|c|c|c|}
\hline $\begin{array}{l}\text { Virus/ } \\
\text { viroid }\end{array}$ & Genome portion & $\begin{array}{l}\text { Nucleotide } \\
\text { (bp) }\end{array}$ & GenBank accession (isolate) & References \\
\hline \multirow{2}{*}{ GVA } & Coat protein & 597 & $\begin{array}{l}\text { AF494187 (Brazil), KF667501 (IT-BA), } \\
\text { AY340581 (SP) }\end{array}$ & $\begin{array}{l}\text { FAJARDO et al., } 2003 \\
\text { MOREIRA et al., 2004b }\end{array}$ \\
\hline & Coat protein & 451 & $\begin{array}{l}\text { HM358052 (PC40), KJ848782 } \\
\text { (NiagRos2), KJ848783 (NiagRos10) }\end{array}$ & BASSO et al., 2010a \\
\hline GVB & Coat protein & 594 & $\begin{array}{l}\text { AF438410 (BR1), KF040331 (CO), } \\
\text { KF040332 (IS-SVF), KF040333 (CS), } \\
\text { AY340582 (Common), AY340583 (Italia) }\end{array}$ & $\begin{array}{l}\text { NICKEL et al., 2002 } \\
\text { MOREIRA et al., 2004a } \\
\text { CATARINO et al., } 2015\end{array}$ \\
\hline GVD & $\begin{array}{l}\text { Coat protein and } \\
\text { RNA-binding } \\
\text { protein }\end{array}$ & 852 & $\begin{array}{l}\text { JQ031715 (Dolc) } \\
\text { JQ031716 (Garg) }\end{array}$ & FAJARDO et al., 2012 \\
\hline GLRaV-1 & Coat protein & 969 & GQ332536 (PS) & FAJARDO et al., 2011 \\
\hline \multirow{4}{*}{ GLRaV-2 } & Coat protein & 597 & $\begin{array}{l}\text { EU053125 (M/C), EU053126 (L/I), } \\
\text { EU204909 (SE), EU204910 (IT), } \\
\text { EU204911 (MH), EU204912 (RI) }\end{array}$ & RADAELLI et al., 2009 \\
\hline & Coat protein & 431 & HM059035 (CS2), HM358050 (IS3) & BASSO et al., 2010a \\
\hline & Coat protein & 397 & KJ958525 (Mer8), KJ958526 (Mer31) & CATARINO et al., 2015 \\
\hline & HSP70 & $596-623$ & HM059039 (CS1), HM130523 (SE) & BASSO et al., 2010a \\
\hline
\end{tabular}


continuation...

TABLE 2- Grapevine viruses and viroids reported in Brazilian vineyards and molecularly characterized.

\begin{tabular}{|c|c|c|c|c|}
\hline \multirow{4}{*}{ GLRaV-3 } & Coat protein & 942 & $\begin{array}{l}\text { DQ680141 (Pet-1), DQ680142 (Pet-2), } \\
\text { DQ062152 (Pet-3), AY753208 (Pet-4), } \\
\text { HM059034 (IS2), KJ704369 (RC-PE) }\end{array}$ & $\begin{array}{l}\text { FAJARDO et al., 2007b } \\
\text { BASSO et al., 2010a }\end{array}$ \\
\hline & Replicase & 340 & AF438411 (Pet-4) & FAJARDO et al., 2002 \\
\hline & HSP70 & 593 & HM059040 (IS1) & BASSO et al., 2010a \\
\hline & HSP70 & 230 & KC519443 (Pet-4) & FAJARDO et al., 2007b \\
\hline GLRaV-4 & HSP70 & 302 & $\mathrm{KC} 202814$ (RB), KC202815 (ME) & CATARINO et al., 2015 \\
\hline \multirow{2}{*}{$\begin{array}{l}\text { GLRaV-4, } \\
\text { strain } 5\end{array}$} & Coat protein & 798 & JQ821315 (Card5) & FAJARDO et al., 2012 \\
\hline & HSP70 & 565 & JQ821314 (Card5) & FAJARDO et al., 2012 \\
\hline $\begin{array}{l}\text { GLRaV-4, } \\
\text { strain } 6\end{array}$ & HSP70 & 591 & JQ290111 (Card) & FAJARDO et al., 2012 \\
\hline \multirow[t]{5}{*}{ GRSPaV } & Coat protein & 780 & $\begin{array}{l}\text { EF636803 (CF195), EF636804 (CF207), } \\
\text { EF690380 (MG), EF690381 (PN), } \\
\text { EF690382 (MH), EF690383 (CF208), } \\
\text { EF690384 (CF210), EU040204 (420A), } \\
\text { EU204913 (CF195-2), GU166289 (CS1), } \\
\text { GU166290 (IS2a), DQ443732 (SP), } \\
\text { KJ848784 (NiagRos4), KJ848785 } \\
\text { (NiagRos5), KT008367 to KT008381 }\end{array}$ & $\begin{array}{l}\text { PEREIRA, } 2008 \\
\text { RADAELLI et al., } 2009 \\
\text { BASSO et al., 2010a } \\
\text { FAJARDO et al., 2015c }\end{array}$ \\
\hline & Replicase & $828-831$ & $\begin{array}{l}\text { AY244640 (Sout. Brazilian), HM059036 } \\
\text { (CS2a), HM059037 (IS1), AY340585 }\end{array}$ & $\begin{array}{l}\text { ESPINHA et al., } 2003 \\
\text { FAJARDO et al., } 2004 \\
\text { BASSO et al., 2010a }\end{array}$ \\
\hline & & 339 & HM059038 (CS2b), HM358051 (IS2b) & BASSO et al., 2010a \\
\hline & & 628 & HM130524 (IS3) & BASSO et al., 2010a \\
\hline & Partial genome & 8716 & KT948710 (VF1) & FAJARDO et al., $2015 \mathrm{c}$ \\
\hline \multirow[t]{2}{*}{ GFLV } & Coat protein & 1515 & $\begin{array}{l}\text { EU258680 (RUP), EU258681 (IAC), } \\
\text { EU038294 (RS) }\end{array}$ & RADAELLI et al., 2009 \\
\hline & Coat protein & 321 & AF418579 (RS) & FAJARDO et al., 2000 \\
\hline GFkV & Coat protein & 693 & JN022610 (BF) & FAJARDO et al., 2012 \\
\hline GRVFV & Coat protein & 474 & KC815703 (MER), KC815704 (SEM) & CATARINO et al., 2015 \\
\hline TFDaV & Complete genome & 3442 & $\begin{array}{l}\text { KJ955449 (MFB15S1), } \\
\text { KR134350 (MFB15S2) }\end{array}$ & BASSO et al., 2015 \\
\hline GVCV & Polyprotein & 472 & KR107537 (CS-BR) & \\
\hline GRGV & Coat protein & 319 & KR107538 (CS-BR) & \\
\hline \multirow[t]{2}{*}{ GSyV-1 } & Partial genome & $\begin{array}{l}6438- \\
6465\end{array}$ & $\begin{array}{l}\text { KR153306 (VF-BR), KT037017 (MH), } \\
\text { KX130754 (TRAJ-BR) }\end{array}$ & FAJARDO et al., 2015c \\
\hline & Coat protein & 627 & KX258763-KX258767 & \\
\hline \multirow{2}{*}{ GCSV } & Partial genome & $1110-3849$ & KR107527 to KR107536 (CS-BR) & \multirow{2}{*}{ FAJARDO et al., $2015 \mathrm{a}$} \\
\hline & $\mathrm{P} 4$ protein & 386 & KR074408 (CS-BR) & \\
\hline EVd & Complete genome & $369-371$ & $\begin{array}{l}\text { DQ444473 (CSC07), DQ444474 } \\
\text { (NiagD11), DQ471994 (CSC09), } \\
\text { DQ471995 (CSC10), DQ471996 (CSC11) }\end{array}$ & EIRAS et al., 2006 \\
\hline
\end{tabular}


continuation...

TABLE 2- Grapevine viruses and viroids reported in Brazilian vineyards and molecularly characterized.

\begin{tabular}{lccll}
\hline GYSVd-1 & Complete genome & 366-367 & $\begin{array}{l}\text { KU668661-KU668665, } \\
\text { KU880712-KU880717 }\end{array}$ & FAJARDO et al., 2015b \\
\hline HSVd & Complete genome & 297 & $\begin{array}{l}\text { DQ444475, DQ444476, DQ471997, } \\
\text { DQ471998 }\end{array}$ & EIRAS et al., 2006 \\
\hline
\end{tabular}

GVA: Grapevine virus A; GVB: Grapevine virus B; GVD: Grapevine virus D; GLRaV: Grapevine leafroll-associated virus; GRSPaV: Grapevine rupestris stem pitting-associated virus; GFLV: Grapevine fanleaf virus; GFkV: Grapevine fleck virus; GRVFV: Grapevine rupestris vein feathering virus; TFDaV: Temperate fruit decay-associated virus; GVCV: Grapevine vein clearing virus; GRGV: Grapevine Red Globe virus; GSyV-1: Grapevine Syrah virus-1; GCSV: Grapevine Cabernet Sauvignon reovirus; CEVd: Citrus exocortis viroi GYSVd-1: Grapevine yellow speckle viroid-1; HSVd: Hop stunt viroid.
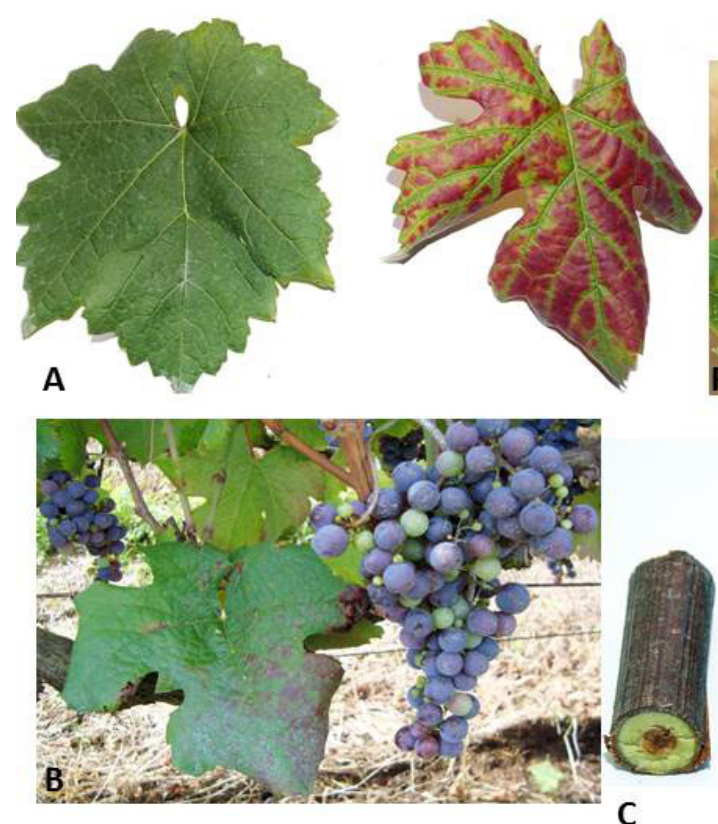

C
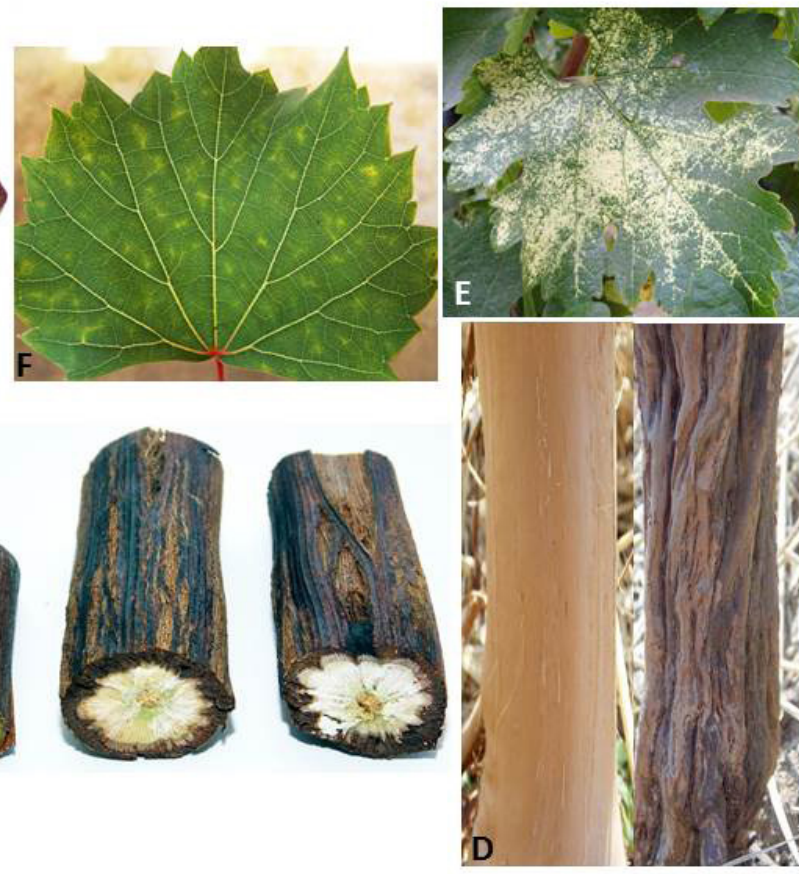

FIGURE 1-Symptoms observed in some grapevine cultivars in Brazilian vineyards: leaf without (left) and with typical symptoms (right) of grapevine leafroll (A) and lack of color in red grapes caused by this disease (B); corky bark in V. labrusca cv. Niagara Rosada (C) and stem pitting in rootstock cv. Paulsen 1103 (D) caused by rugose wood complex (healthy grapevines in left side of pictures); fanleaf degeneration (E); and fleck disease in grapevine (Vitis rupestris St. George) (F). Photos: Thor V. M. Fajardo. 


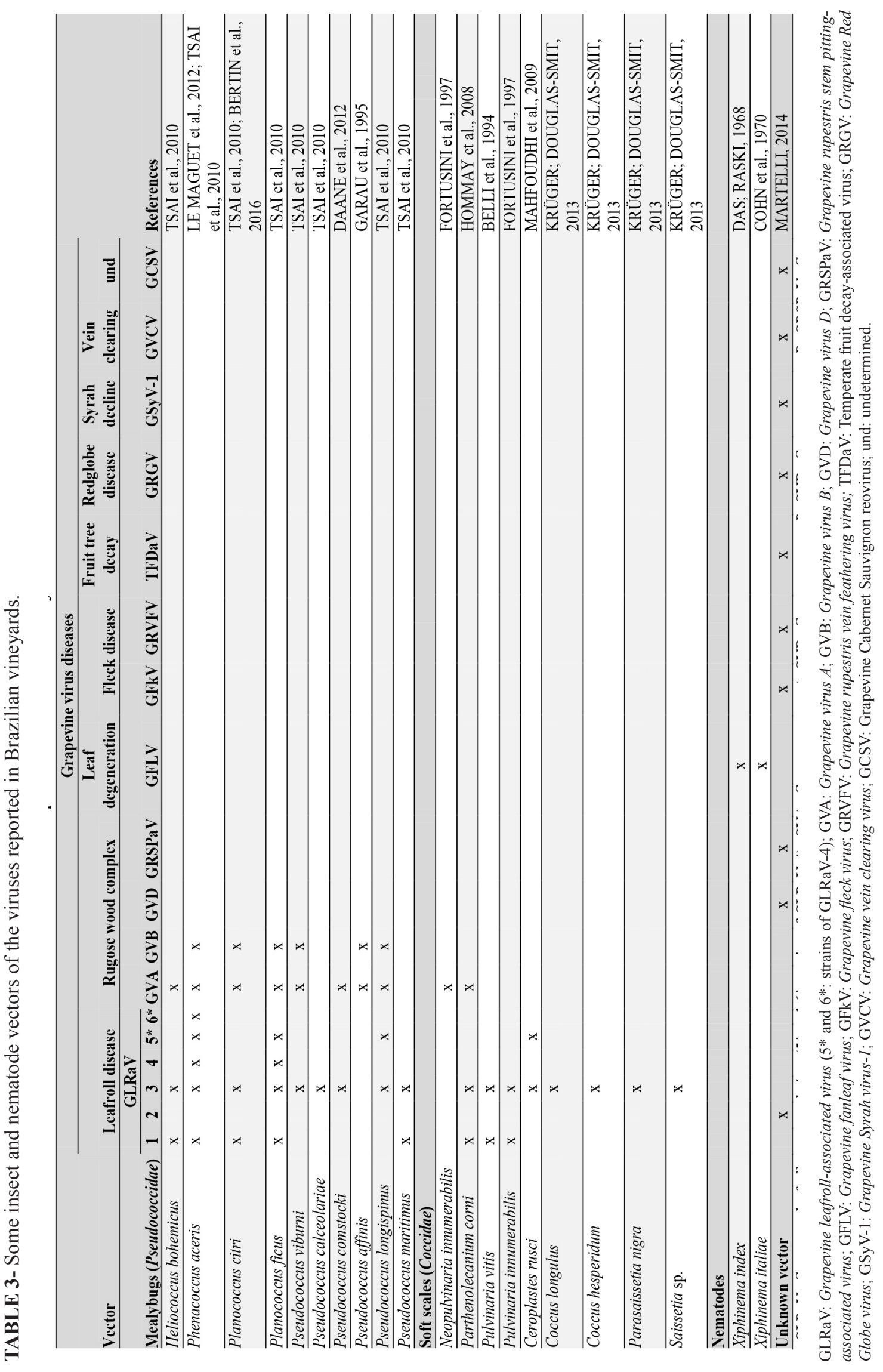




\section{CONCLUSION AND FUTURE PROSPECTS}

The main prophylactic measure for the control of grapevine viruses is the use of propagation material free of viruses. Pathogen-derived resistance or transgenic technologies can provide means to achieve resistance in grapevine hybrids or rootstocks. However they are far from being widely established commercially. The utilization of NGS associated with expertise in bioinformatics is a powerful tool to investigate the grapevine virome. Several new pathogenic agents were recently identified and associated with important grapevine diseases. The application of these knowledge and technologies in grapevine quarantine and certification programs can improve the efficiency of these programs, contributing to control viral diseases worldwide.

\section{REFERENCES}

ABDULlAHI, I.; GRYSHAN, Y.; ROTT, M. Amplification-free detection of grapevine viruses using an oligonucleotide microarray. Journal of Virological Methods, Amsterdam, v.178, n.1-2, p.1-15, 2011.

AKKURT, M. Comparison between modified DNA extraction protocols and commercial isolation kits in grapevine (Vitis vinifera L.). Genetics and Molecular Research, Ribeirão Preto, v.11, n.3, p.2343-2351, 2012.

AL RWAHNIH, M.; DAUBERT, S.; GOLINO, D.; ISLAS, C.; ROWHANI, A. Comparison of nextgeneration sequencing versus biological indexing for the optimal detection of viral pathogens in grapevine. Phytopathology, Saint Paul, v.105, n.6, p.758-763, 2015.

AL RWAHNIH, M.; DAUBERT, S.; GOLINO, D.; ROWHANI, A. Deep sequencing analysis of RNAs from a grapevine showing Syrah decline symptoms reveals a multiple virus infection that includes a novel virus. Virology, New York, v.387, n.2, p.395401, 2009.

ALRWAHNIH, M.; DAUBERT, S.; SUDARSHANA, M. R.; ROWHANI, A. Gene from a novel plant virus satellite from grapevine identifies a viral satellite lineage. Virus Genes, Norwell, v.47, n.1, p.114118, 2013a.
AL RWAHNIH, M.; DAVE, A.; ANDERSON, M. M.; ROWHANI, A.; UYEMOTO, J. K.; SUDARSHANA, M. R. Association of a DNA virus with grapevines affected by Red blotch disease in California. Phytopathology, Saint Paul, v.103, n.10, p.1069-1076, 2013b.

AL RWAHNIH, M.; GOLINO, D.; ROWHANI, A. First report of Grapevine Pinot gris virus infecting grapevine in the United States. Plant Disease, Saint Paul, v.100, n.5, p.1030. 2016.

AL RWAHNIH, M.; OSMAN, F.; SUDARSHANA, M.; UYEMOTO, J.; MINAFRA, A.; SALDARELLI, P.; MARTELLI, G.; ROWHANI, A. Detection of Grapevine leafroll-associated virus 7 using real time qRT-PCR and conventional RT-PCR. Journal of Virological Methods, Amsterdam, v.179, n.2, p. 383-389, 2012.

ALABI, O. J.; CASASSA, L. F.; GUTHA, L. R.; LARSEN, R. C.; HENICK-KLING, T.; HARBERTSON, J. F.; NAIDU, R. A. Impacts of grapevine leafroll disease on fruit yield and grape and wine chemistry in a wine grape (Vitis vinifera L.) cultivar. PloS One, San Francisco, v.11, e0149666, 2016.

ALMEIDA, R. P.P.; DAANE, K. M.; BELL, V.A.; BLAISDELL, G. K.; COOPER, M. L.; HERRBACH, E.; PIETERSEN, G. Ecology and management of grapevine leafroll disease. Frontiers in Microbiology, New York, v.4, n.94, 2013.

ANDRET-LINK, P.; LAPORTE, C.; VALAT, L.; RITZENTHALER, C.; DEMANGEAT, G.; VIGNE, E.; LAVAL, V.; PFEIFFER, P.; STUSSI-GARAUD, C.; FUCHS, M. Grapevine fanleaf virus: still a major threat to the grapevine industry. Journal of Plant Pathology, Bari, v.86, n.3, p.183-195, 2004.

ATALLAH, S.S.; GOMEZ, M.I.; FUCHS, M.F.; MARTINSON, T.E. Economic impact of grapevine leafroll disease on Vitis vinifera cv.Cabernet franc in Finger Lakes vineyards of New York. American Journal of Enology and Viticulture, Davis, v.63, n.1, p.73-79, 2012.

BARÁNEK, M.; RADDOVÁ, J.; KRIZAN, B.; PITRA, M. Genetic changes in grapevine genomes after stress induced by in vitro cultivation, thermotherapy and virus infection as revealed by AFLP. Genetics and Molecular Biology, Ribeirão Preto, v.32, n.4, p.834-839, 2009. 
BARBA, M.; CZOSNEK, H.; HADIDI, A. Historical perspective, development and applications of nextgeneration sequencing in plant virology. Viruses, Switzerland, v.6, n.1, p.106-136, 2014.

BARBA, M.; ILARDI, V.; PASQUINI, G. Control of Pome and Stone Fruit Virus Diseases. In: LOEBENSTEIN, G.; KATIS, K.I. (Ed.). Advances in Virus Research. Burlington: Academic Press, 2015. p.47-83.

BASSO, M. F.; FAJARDO, T. V.M.; EIRAS, M.; AYUB, R. A.; NICKEL, O. Detecção e identificação molecular de vírus associados a videiras sintomáticas e assintomáticas. Ciência Rural, Santa Maria, v.40, n.11, p.2249-2255, 2010a.

BASSO, M.F.; FAJARDO, T.V.M.; EIRAS, M.; AYUB, R.A.; NICKEL, O. Produção de antissoro policlonal utilizando a proteína capsidial recombinante do Rupestris stem pitting-associated virus. Ciência Rural, Santa Maria, v.40, n.11, p.2385-2388, 2010 b.

BASSO, M.F.; FAJARDO, T.V.M.; PIO-RIBEIRO, G.; EIRAS, M.; ZERBINI, F.M. Avanços e perspectivas no estudo das doenças virais e subvirais em videira com ênfase na realidade brasileira. Revisão Anual de Patologia de Plantas, Passo Fundo, v.22, p.160-207, 2014.

BASSO, M.F.; FAJARDO, T.V.M.; SANTOS, H.P.; GUERRA, C.C.; AYUB, R.A.; NICKEL, O. Fisiologia foliar e qualidade enológica da uva em videiras infectadas por vírus. Tropical Plant Pathology, Brasília, DF, v.35, n.6, p.351-359, 2010c.

BASSO, M.F.; SILVA, J.C.F.da.; FAJARDO, T.V.M.; FONTES, E.P.B.; ZERBINI, F.M. A novel, highly divergent ssDNA virus identified in Brazil infecting apple, pear and grapevine. Virus Research, Amsterdam, v.210, p.27-33, 2015.

BATTANY, M.; ROWHANI, A.; GOLINO, D. Syrah in California, decline or disorder? Practical Winery Vineyards, San Rafael, p.1-7, may/june 2004.

BAYATI, S.; SHAMS-BAKHSH, M.; MOIENI, A. Elimination of Grapevine virus A (GVA) by cryotherapy and electrotherapy. Journal of Agricultural Science and Technology, Tehran, v.13, n.3, p.442-450, 2011.
BEBER, R.; DE LILLO, E.; MALAGNINI, V.; GUALANDRI, V.; POGGI POLLINI, C.; RATTI, C.; SALDARELLI, P.; VALENZANO, D.; VERNILE, P.; TERLIZZI, F. Transmission trials of Grapevine Pinot gris virus by the eriophyoid mite Colomerus vitis. Journal of Plant Pathology, Bari, v.95, n.4, p.35-67, 2013. Suppl.

BELL, V.A.; BONFIGLIOLI, R.G.E.; WALKER, J.T.S.; LO, P.L.; MACKAY, J.F.; MCGREGOR, S.E. Grapevine leafroll-associated virus 3 persistence in Vitis vinifera remnant roots. Journal of Plant Pathology, Bari, v.91, n.3, p.527-533, 2009.

BELLI, G.; FORTUSINI, A.; CASATI, P.; BELLI, L.; BIANCO, P.A.; PRATI, S. Transmission of a Grapevine leafroll associated closterovirus by the scale insect Pulvinaria vitis L. Rivista di PatologiaVegetale, Torino, v.4, n.3, p.105-108, 1994.

BERTIN, S.; PACIFICO, D.; CAVALIERI, V.; MARZACHİ, C.; BOSCO, D. Transmission of Grapevine virus A and Grapevine leafroll-associated viruses 1 and 3 by Planococcus ficus and Planococcus citri fed on mixed-infected plants. Annals of Applied Biology, Warnick, v.169, n.1, p.53-63, 2016.

BESTER, R.; JOOSTE, A.E.; MAREE, H.J.; BURGER, J.T. Real-time RT-PCR high-resolution melting curve analysis and multiplex RT-PCR to detect and differentiate Grapevine leafrollassociated virus 3 variant groups I, II, III and VI. Virology Journal, London, v.9, n.219, 2012. doi: 10.1186/1743-422X-9-219.

BEUVE, M.; CANDRESSE, T.; TANNIÈRES, M.; LEMAIRE, O. First report of Grapevine Pinot gris virus (GPGV) in grapevine in France. Plant Disease, Saint Paul, v.99, n.2, p.293-293, 2015.

BEUVE, M.; SEMPÉ, L.; LEMAIRE, O. A sensitive one-step real-time RT-PCR method for detecting Grapevine leafroll-associated virus 2 variants in grapevine. Journal of Virological Methods, Amsterdam, v.141, n.2, p.117-124, 2007.

B O R R O T O - F E R N A N D E Z, E. G .; SOMMERBAUER, T.; POPOWICH, E.; SCHARTL, A.; LAIMER, M. Somatic embryogenesis from anthers of the autochthonous Vitis vinifera $\mathrm{cv}$. Domina leads to Arabis mosaic virus-free plants. European Journal of Plant Pathology, Dordrecht, v.124, n.1, p.171-174, 2009. 
BURGER, J.T.; MAREE, H.J. Metagenomic next-generation sequencing of viruses infecting grapevines. Methods in Molecular Biology, Clifton, v.1302, p.315-330, 2015.

CALVI, B.L. Effects of red-leaf disease on Cabernet Sauvignon at the Oakville experimental vineyard and mitigation by harvest delay and crop adjustment. 2011. $78 \mathrm{f}$. Thesis (Master of Sciense in Viticulture and Enology) - University of California, Davis, 2011.

CAMARGO, U.A.; TONIETTO, J.; HOFFMANN, A. Progressos na viticultura brasileira. Revista Brasileira de Fruticultura, Jaboticabal, v.33, n.1, p.144-149, 2011.

CATARINO, A. de M.; FAJARDO, T.V.M.; PIORIBEIRO, G.; EIRAS, M.; NICKEL, O. Incidência de vírus em videiras no Nordeste brasileiro e caracterização molecular parcial de isolados virais locais. Ciência Rural, Santa Maria, v.45, n.3, p.379385, 2015.

CHIUMENTI, M.; MOHORIANU, I.; ROSETI, V.; SALDARELLI, P.; DALMAY, T.; MINAFRA, A. High-throughput-sequencing-based identification of a Grapevine fanleaf virus satellite RNA in Vitis vinifera. Archives of Virology, New York, v.161, n.5, p.1401-1403, 2016.

COETZEE, B.; FREEBOROUGH, M.J.; MAREE, H.J.; CELTON, J.M.; REES, D.J.; BURGER, J.T. Deep sequencing analysis of viruses infecting grapevines: Virome of a vineyard. Virology, New York, v.400, n.2, p.157-163, 2010.

COHN, E.; TANNE, E.; NITZANY, F.E. Xiphinema italiae, a new vector of Grapevine fanleaf virus. Phytopathology, Saint Paul, v.60, n.1, p.181-182, 1970.

CRETAZZO, E.; PADILlA, C.; BOTA, J.; ROSSELLÓ, J.; VADELL, J.; CIFRE, J. Virus interference on local scale viticulture: the case of Moll variety from Majorca (Spain). Scientia Agricola, Piracicaba, v.70, n.2, p.125-136, 2013.

CRETAZZO, E.; PADILlA, C.; CARAMBULA, C.; HITA, I.; SALMERÓN, E.; CIFRE, J. Comparison of the effects of different virus infections on performance of three Majorcan grapevine cultivars in field conditions. Annals of Applied Biology, Warnick, v.156, v.1, p.1-12, 2010.
DAANE, K.M.; ALMEIDA, R.P.P.; BELL, V.A.; WALKER, T.S.; BOTTON, M.; FALLAHZADEH, M.; MANI, M.; MIANO, J.L.; SFORZA, R.; WALTON, V.M.; ZAZEIZO, T. Biology and management of mealybugs in vineyards. In: BOSTANIAN, N.J.; VINCENT, C.; ISAACS, R. (Ed.). Arthropod management in vineyards: pests, approaches, and future directions. Netherlands: Springer, 2012. cap.12, p.271-308.

DAS, S.; RASKI, D.J. Vector-efficiency of Xiphinema index in the transmission of Grapevine fanleaf virus.

Nematologica, Leiden, v.14, p.55-62, 1968.

DEMANGEAT, G.; KOMAR, V.; VAN-GHELDER, C.; VOISIN, R.; LEMAIRE, O.; ESMENJAUD, D.; FUCHS, M. Transmission competency of single female Xiphinema index lines for Grapevine fanleaf virus. Phytopathology, Saint Paul, v.100, n.4, p.384389, 2010.

DUBIELA, C.R.; FAJARDO, T.V.M.; SOUTO, E.R.; NICKEL, O.; EIRAS, M.; REVERS, L.F. Simultaneous detection of Brazilian isolates of grapevine viruses by TaqMan real-time RT-PCR. Tropical Plant Pathology, Brasília, DF, v.38, n.2, p.158-165, 2013.

EIRAS, M.; TARGON, M.L.P.N.; FAJARDO, T.V.M.; FLORES, R.; KITAJIMA, E.W. Citrus exocortis viroid and Hop stunt viroid doubly infecting grapevines in Brazil. Fitopatologia Brasileira, Brasília, DF, v.31, n.5, p.440-446, 2006.

ENGEL, E.A.; RIVERA, P.A.; VALENZUELA, P.D.T. First report of Grapevine Syrah virus-1 in Chilean grapevines. Plant Disease, Saint Paul, v.94, n.5, p.633, 2010.

ESPINHA, L.M.; GASPAR, J.O.; KUNIYUKI, H.; CAMARGO, L.E.A. Molecular detection of Rupestris stem pitting-associated virus in grapevines in Brazil. Fitopatologia Brasileira, Brasília, DF, v.28, n.2, p.206-206, 2003.

ESPINOZA, C.; VEGA, A.; MEDINA, C.; SCHLAUCH, K.; CRAMER, G.; ARCE-JOHNSON, P. Gene expression associated with compatible viral diseases in grapevine cultivars. Functional and Integrative Genomics, Berlin, v.7, n.2, p.95-110, 2007. 
FAJARDO, T.V.M.; NICKEL, O.; EIRAS, M.; KUHN, G.B. Detecção de um isolado de Grapevine virus $A$ e caracterização do gene da proteína capsidial. Fitopatologia Brasileira, Brasília, DF, v.28, n.5, p.521-527, 2003.

FAJARDO, T.V.M.; AL RWAHNIH, M.; NAGATA, T.; MELO, F.L. First report of grapevine reovirus infecting Cabernet Sauvignon grapevine in Brazil. In: BRAZILIAN CONGRESS OF VIROLOGY, 26.; MERCOSUR MEETING OF VIROLOGY, 10., 2015, Florianópolis. Anais... Florianópolis: SBV, 2015a. p.188.

FAJARDO, T.V.M.; BARROS, D.R.; NICKEL, O.; KUHN, G.B.; ZERBINI, F.M. Expression of Grapevine leafroll-associated virus 3 coat protein gene in Escherichia coli and production of polyclonal antibodies. Fitopatologia Brasileira, Brasília, DF, v.32, n.6, p.496-500, 2007a.

FAJARDO, T.V.M.; DIANESE, E.C.; EIRAS, M.; CERQUEIRA, D.M.; LOPES, D.B.; FERREIRA, M.A.S.V.; MARTINS, C.R.F. Variability of the coat protein gene of Grapevine leafroll-associated virus 3 in Brazil. Fitopatologia Brasileira, Brasília, DF, v.32, n.4, p.335-340, $2007 \mathrm{~b}$

FAJARDO, T.V.M.; EIRAS, M.; NICKEL, O. Grapevine yellow speckle viroid 1 detected in symptomatic grapevines in Brazil. In: CONGRESSO BRASILEIRO DE VITICULTURA E ENOLOGIA, 13., 2015; CONGRESSO LATINO-AMERICANO DE VITICULTURA E ENOLOGIA, 15. 2015, Bento Gonçalves, RS. Resumos... Bento Gonçalves, RS: Embrapa Uva e Vinho, 2015b. p.287.

FAJARDO, T.V.M.; EIRAS, M.; NICKEL, O.; DUBIELA, C.R.; SOUTO, E.R. de. Detection and partial molecular characterization of Grapevine fleck vir Grapevine virus D, Grapevine leafroll-associated virus 5 and 6 infecting grapevines in Brazil. Ciência Rural, Santa Maria, v.42, n.12, p.2127-2130, 2012.

FAJARDO, T.V.M.; EIRAS, M.; SANTOS, H. P.; NICKEL, O.; KUHN, G. B. Detecção e caracterização biológica e molecular de Rupestris stem-pitting associated virus e seu efeito na fotossíntese de videiras. Fitopatologia Brasileira, Brasília, DF, v.29, n.2, p.209-214, 2004.
FAJARDO, T.V.M.; KUHN, G.B.; EIRAS, M.; NICKEL, O. Caracterização parcial de um isolado do Grapevine fanleaf virus. Fitopatologia Brasileira, Brasília, DF, v.25, n.3, p.505-511, 2000.

FAJARDO, T.V.M.; KUHN, G.B.; EIRAS, M.; NICKEL, O. Detecção de Closterovirus em videira e caracterização parcial de um isolado do Grapevine leafroll-associated virus 3. Fitopatologia Brasileira, Brasília, DF, v.27, n.1, p.58-64, 2002.

FAJARDO, T.V.M.; NAGATA, T.; MELO, F. L. Next generation sequencing applied for identification of three new viruses infecting grapevine in Brazil. In: CONGRESSO BRASILEIRO DE VITICULTURA E ENOLOGIA, 13., 2015; CONGRESSO LATINOAMERICANO DE VITICULTURA E ENOLOGIA, 15. 2015, Bento Gonçalves. Resumos... Bento Gonçalves: Embrapa Uva e Vinho, 2015c, p.288.

FAJARDO, T.V.M.; NICKEL, O.; EIRAS, M. Detecção e caracterização molecular dos genes da proteína capsidial de ilarvírus e ampelovírus que infectam fruteiras temperadas. Ciência Rural, Santa Maria, v.41, n.1, p.5-9, 2011.

FAN, X. D.; DONG, Y. F.; ZHANG, Z. P.; REN, F., HU, G. J., LI, Z. N.; ZHOU, J. First report of Grapevine Pinot gris virus from grapevines in China. Plant Disease, Saint Paul, v.100, n.2. p.540, 2016.

FIORE, N. Enfermedades de la vid causadas por virus viroides y fitoplasmas: diagnóstico, epidemiología y control. In: CONGRESSO BRASILEIRO DE VITICULTURA E ENOLOGIA, 13., 2015; CONGRESSO LATINO-AMERICANO DE VITICULTURA E ENOLOGIA, 15. 2015, Bento Gonçalves, RS. Resumos...Bento Gonçalves, RS: Embrapa Uva e Vinho, 2015. p.118-130.

FORTUSINI, A.; SCATTINI, G.; PRATI, S.; CINQUANTA, S.; BELL, G. Transmission of Grapevine leafroll virus 1 (GLRaV-1) and Grapevine virus $A$ (GVA) by scale insects. In: MEETING OF ICVG, 12., 1997. Abstract... Lisbon: ICVG, 1997. p.121-122. 
FUCHS, M.; CAMBRA, M.; CAPOTE, N.; JELKMANN, W.; KUNDU, J.; LAVAL, V.; MARTELLI, G.P.; MINAFRA, A.; PETROVIC, N.; PFEIFER, P.; POMPE-NOVAK, M.; RAVELONANDRO, M.; SALDARELLI, P.; STUSSI-GARAUD, C.; VIGNE, E.; ZAGRAI, I. Safety assessment of transgenic plums and grapevines expressing viral coat protein genes: new insights into real environmental impact of perennial plants engineered for virus resistance. Journal of Plant Pathology, Bari, v.89, n.1, p.5-12, 2007.

FUCHS, M.; KRENZ, B.; YEPES, L. M.; THOMPSON, J.; MCLANE, H. L.; PERRY, K. L. Is Grapevine red blotch-associated virus the causal agent of red blotch disease? In: CONGRESS OF INTERNATIONAL COUNCIL FOR THE STUDY OF VIRUS AND VIRUS-LIKE DISEASES OF THE GRAPEVINE, 18., 2015, Ankara.. Proceedings... Ankara: ICVG - International Council for the Study of Virus and Virus-like Diseases of the Grapevine, 2015. p.72.

GAMBINO, G.; NAVARRO, B.; VALLANIA, R.; GRIBAUDO, I.; DI SERIO, F. Somatic embryogenesis efficiently eliminates viroid infections from grapevines. European Journal of Plant Pathology, Dordrecht, v.130, n.4, p.511-519, 2011.

GAMBINO, G.; PERRONE, I.; CARRA, A.; CHITARRA, W.; BOCCACCI, P.; MARINONI, D. T.; BARBERIS, M.; MAGHULY, F.; LAIMER, M.; GRIBAUDO, I. Transgene silencing in grapevines transformed with GFLV resistance genes: analysis of variable expression of transgene, siRNAs production and cytosine methylation.Transgenic Research, London, v.19, n.1, p.17-27, 2010.

GARAU, R.; PROTA, V.A.; BOSCIA, D.; FIORI, M.; PROTA, U. Pseudococcus affinis Mask., new vector of Grapevine trichoviruses $A$ and $B$. Vitis, Siebeldingen, v.34, p.67-68, 1995.

GAZEL, M.; CAGLAYAN, K.; ELÇI, E.; ÖZTÜRK, L. First report of Grapevine Pinot gris virus in grapevine in Turkey. Plant Disease, St Paul, v.100, n.3, p.657-657, 2016.
GIAMPETRUZZI,A.; MORELLI,M.; CHIUMENTI, M.; SAVINO, V.N.; MARTELLI, G. P.; LANOTTE, P.; PALMISANO, F.; SALDARELLI, P. Towards the definition of the absolute sanitary status of certified grapevine clones and rootstocks. IN: CONGRESS OF INTERNATIONAL COUNCIL FOR THE STUDY OF VIRUS AND VIRUS-LIKE DISEASES OF THE GRAPEVINE, 18., 2015, Ankara. Proceedings... Ankara: ICVG- International Council for the Study of Virus and Virus-like Diseases of the Grapevine, 2015. p.146.

GIAMPETRUZZI, A.; ROUMI, V.; ROBERTO, R.; MALOSSINI, U.; YOSHIKAWA, N.; LA NOTTE, P.; TERLIZZI, F.; CREDI, R.; SALDARELLI, P.A new grapevine virus discovered by deep sequencing of virus- and viroid-derived small RNAs in cv. Pinot gris. Virus Research, Amsterdam, v.163, n.1, p.262268, 2012

GIRIBALDI, M.; PURROTTI, M.; PACIFICO, D.; SANTINI, D.; MANNINI, F.; CACIAGLI, P.; ROLLE, L.; CAVALLARIN, L.; GIUFFRIDA, M. G.; MARZACHI, C. A multidisciplinary study on the effects of phloem-limited viruses on the agronomical performance and berry quality of Vitis vinifera cv. Nebbiolo. Journal of Proteomics, New York, v.75, n.1, p.306-315, 2011.

GLASA, M.; PREDAJNA, L.; KOMINEK, P.; NAGYOVÁ, A.; CANDRESSE, T.; OLMOS, A. Molecular characterization of divergent Grapevine Pinot gris virus isolates and their detection in Slovak and Czech grapevines. Archives of Virology, New York, v.159, n.8, p.2103-2107, 2014.

GLASA, M.; PREDAJNA, L.; SOLTYS, K.; SABANADZOVIC, S.; OLMOS, A. Detection and molecular characterization of Grapevine Syrah virus-1 isolates from Central Europe. Virus Genes, Norwell, v.51, n.1, p.112-121, 2015.

GUALANDRI, V.; ASQUINI, E.; BIANCHEDI, P.; COVELLI, L.; BRILLI, M.; MALOSSINI, U.; BRAGAGNA, P.; SALDARELLI, P.; SIAMMOUR, A. Identification of herbaceous hosts of the Grapevine Pinot gris virus (GPGV). European Journal of Plant Pathology, Dordrecht, v.147, n.1, p.21-25, 2017. 
GUO, Q.; HONESTY, S.; XU, M. L.; ZHANG, Y.; SCHOELZ, J.; QIU, W. Genetic diversity and tissue and host specificity of Grapevine vein clearing virus. Phytopathology, Saint Paul, v.104, n.5, p.539-547, 2014.

GUTHA, L.R.; CASASSA, L.F.; HARBERTSON, J.F.; NAIDU, R.A. Modulation of flavonoid biosynthetic pathway genes and anthocyanins due to virus infection in grapevine (Vitis vinifera L.) leaves. BMC Plant Biology, London, v.10, n.187, p.1-18, 2010.

HOMMAY, G.; KOMAR, V.; LEMAIRE, O.; HERRBACH, E. Grapevine virus $A$ transmission by larvae of Parthenolecanium corni. European Journal of Plant Pathology, Dordrecht, v.121, n.2, p.185-188, 2008.

HWANG, C.F.; XU, K.; HU, R.; ZHOU, R.; RIAZ, S.; WALKER, M. A. Cloning and characterization of XiR1, a locus responsible for dagger nematode resistance in grape. Theoretical and Applied Genetics, Berlin, v.121, n.4, p.789-799, 2010.

ICTV - International Committee on Taxonomy of Viruses. Available in: <http://www.ictvonline.org/ >. Accessed in december 4th. 2015.

INOUE-NAGATA, A. K.; ALBUQUERQUE, L. C.; ROCHA, W. B.; NAGATA, T. A simple method for cloning the complete begomovirus genome using the bacteriophage $\varphi 29$ DNA polymerase. Journal of Virological Methods, Amsterdam, v.116, n.2, p.209-211, 2004.

JO, Y.; CHOI, H.; KYONG CHO, J.; YOON, J.-Y.; CHOI, S.-K.; KYONG CHO, W. In silico approach to reveal viral populations in grapevine cultivar Tannat using transcriptome data. Scientific Reports, Sidney, v.5, n.15841, 2015. doi: 10.1038/srep15841.

KING, A. M. Q.; ADAMS, M. J.; CARSTENS, E. B.; LEFKOWITZ, E. J. Virus tTaxonomy: Ninth report of the International Committee on Taxonomy of Viruses. San Diego: Elsevier Academic Press, 2012.

KOMAR, V.; VIGNE, E.; DEMANGEAT, G.; LEMAIRE, O.; FUCHS, M. Cross-protection as control strategy against Grapevine fanleaf virus in naturally infected vineyards. Plant Disease, Saint Paul, v.92, n.12, p.1689-1694, 2008.
KRENZ, B.; THOMPSON, J. R.; FUCHS, M.; PERRY, K. L. Complete genome sequence of a new circular DNA virus from grapevine. Journal of Virology, Washington, v.86, n.14, p.7715, 2012.

KRENZ, B.; THOMPSON, J. R.; MCLANE, H. L.; FUCHS, M.; PERRY, K. L. Grapevine red blotchassociated virus is widespread in the United States. Phytopathology, Saint Paul, v.104, n.11, p.12321240, 2014

KRIZAN, B.; ONDRUSIKOVA, E.; HOLLEINOVA, V.; MORAVCOVA, K.; BLAHOVA, L. Elimination of Grapevine fanleaf virus in grapevine by in vivo and in vitro thermotherapy. Horticultural Science, Prague, v.36, n.3, p.105-108, 2009.

KRÜGER, K.; DOUGLAS-SMIT, N. Grapevine leafroll-associated virus $3(\mathrm{GLRaV}-3)$ transmission by three soft scale insect species (Hemiptera: Coccidae) with notes on their biology. African Entomology, Pretoria, v.21, n.1, p.1-8, 2013.

KUMAR, S.; RAI, R.; BARANWAL, V.K. Development of an immunocapture-reverse transcription-polymerase chain reaction (IC-RTPCR) using modified viral RNA release protocol for the detection of Grapevine leafroll-associated virus 3 (GLRaV-3). Phytoparasitica, Bet Dagan, v.43, n.3, p.311-316, 2015.

LAIMER, M.; LEMAIRE, O.; HERRBACH, E. H.; GOLDSCHIMIDT, V.; MINAFRA, A.; BIANCO, P.; WETZEL, T. Resistance to viruses, phytoplasmas and their vectors in the grapevine in Europe: A review. Journal of Plant Pathology, Bari, v.91, n. 1, p.7-23, 2009

LE MAGUET, J.; BEUVE, M.; HERRBACH, E.; LEMAIRE, O. Transmission of six ampeloviruses and two vitiviruses to grapevine by Phenacoccus aceris (Signoret). Phytopathology, Saint Paul, v.102, n.7, p.717-723, 2012.

LÓPEZ-FABUEL, I.; WETZEL, T.; BERTOLINI, E.; BASSLER, A.; VIDAL, E.; TORRES, L. B.; YUSTE, A.; OLMOS, A. Real-time multiplex RTPCR for the simultaneous detection of the five main grapevine viruses. Journal of Virological Methods, Amsterdam, v.188, n.1-2, p.21-24, 2013. 
LUVISI, A.; PANATTONI, A.; TRIOLO, E. Thiopurine prodrugs for plant chemotherapy purposes. Journal of Phytopathology, Berlin, v.159, n.5, p.390-392, 2011.

MAHFOUDHI, N.; DIGIARO, M.; DHOUIBI, M. H. Transmission of Grapevine leafroll viruses by Planococcus ficus (Hemiptera: Pseudococcidae) and Ceroplastes rusci (Hemiptera: Coccidae). Plant Disease, Saint Paul, v.93, n.10, p.999-1002, 2009.

MALAGNINI, V.; DE LILLO, E.; SALDARELLI, P.; BEBER, R.; DUSO, C.; RAIOLA, A.; ZANOTELLI, L.; VALENZANO, D.; GIAMPETRUZZI, A.; MORELLI, M.; RATTI, C.; CAUSIN, R.; GUALANDRI, V. Transmission of Grapevine Pinot gris virus by Colomerus vitis (Acari: Eriophyidae) to grapevine. Archives of Virology, New York, v.161, n.9, p.2595-2599, 2016.

MALIOGKA, V.I.; MARTELLI, G. P.; FUCHS, M.; KATIS, N.I. Control of viruses infecting grapevine. Advances in Virus Research, Burlington: Academic Press, v.91, p.175-227, 2015a.

MALIOGKA, V.I.; OLMOS, A.; PAPPI, P.G.; LOTOS, L.; EFTHIMIOU, K.; GRAMMATIKAKI, G.; CANDRESSE, T.; KATIS, N.I.; AVGELIS, A. D. A novel grapevine badnavirus is associated with the Roditis leaf discoloration disease. Virus Research, Amsterdam, v.203, p.47-55, 2015 b.

MALIOGKA, V.I.; SKIADA, F. G.; ELEFTHERIOU, E. P.; KATIS, N.I. Elimination of a new Ampelovirus (GLRaV-Pr) and Grapevine rupestris stem pitting associated virus (GRSPaV) from two Vitis vinifera cultivars combining in vitro thermotherapy with shoot tip culture. Scientia Horticulturae, Amsterdam, v.123, n.2, p.280-282, 2009.

MAREE, H.J.; ALMEIDA, R.P.P.; BESTER, R.; CHOOI, K.M.; COHEN, D.; DOLJA, V.V.; FUCHS., M.F.; GOLINO, D.A.; JOOSTE, A.E.C.; MARTELLI, G.P.; NAIDU, R.A.; ROWHANI, A.; SALDARELLI, P.; BURGER, J.T. Grapevine leafroll-associated virus 3. Frontiers in Microbiology, New York, v.4, n.82, p.1-21, 2013.

MARTELLI, G. P. Directory of virus and virus-like diseases of the grapevine and their agents. Journal of Plant Pathology, Bari, v.96, n.1, p.1-136, 2014. Suppl.
MARTELLI, G.P.; ABOU GHANEMSABANADZOVIC, N.; AGRANOVSKY, A.A.; AL RWAHNIH, M.; DOLJA, V.V.; DOVAS, C.I.; FUCHS, M.; GURGELI, P.; HU, J.S.; JELKMANN, W.; KATIS, N.I.; MALIOGKA, V.I.; MELZER, M.J.; MENZEL, W.; MINAFRA, A.; ROTT, M.E.; ROWHANI, A.; SABANADZOVIC, S.; SALDARELLI, P. Taxonomic revision of the family Closteroviridae with special reference to the grapevine leafroll-associated members of the genus Ampelovirus and the putative species unassigned to the family. Journal of Plant Pathology, Bari, v.94, n.1, p.7-19, 2012.

MARTELLI, G.P.; ADAMS, M.J.; KREUZE, J.F.; DOLJA, V.V. Family Flexiviridae: a case study in virion and genome plasticity. Annual Review Phytopathology, Palo Alto, v.45, p.73-100, 2007.

MARTELLI, G.P.; SALDARELLI, P. Phytosanitary challenges for the Mediterranean viticultural industry: emerging grapevine viruses. Montpellier: CIHEAM, 2015. (Watch Letter, 33)

MOREIRA, A.E.; GASPAR, J.O.; CAMARGO, L.E.A.; KUNIYUKI, H. Caracterização do gene da proteína capsidial de dois isolados, patologicamente distintos e sorologicamente semelhantes, do Grapevine virus $B$ em videiras no Estado de São Paulo. Fitopatologia Brasileira, Brasília, DF, v.29, n.1, p.75-80, 2004a.

MOREIRA, A.E.; GASPAR, J.O.; CAMARGO, L.E.A.; KUNIYUKI, H. Caracterização do gene da proteína capsidial do Grapevine virus $A$ em videiras afetadas pela acanaladura do lenho de Kober no Estado de São Paulo. Fitopatologia Brasileira, Brasília, DF, v.29, n.2, p.205-208, 2004b.

NAIDU, R.; ROWHANI, A.; FUCHS, M.; GOLINO, D.; MARTELLI, G. P. Grapevine leafroll: A complex viral disease affecting a high-value fruit crop. Plant Disease, Saint Paul, v.98, n.9, p.1172-1185, 2014.

NAIDU, R.A.; MAREE, H.J.; BURGER, J.T. Grapevine leafroll disease and associated viruses: a unique pathosystem. Annual Review of Phytopathology, Palo Alto, v.53, p.613-634, 2015. 
NASCIMENTO, M.B.; FAJARDO, T.V.M.; EIRAS, M.; CZERMAINSKI, A.B.C.; NICKEL, O.; PIORIBEIRO, G. Desempenho agronômico de videiras com e sem sintomas de viroses, e comparação molecular de isolados virais. Pesquisa Agropecuária Brasileira, Brasília, DF, v.50, n.7, p.541-550, 2015.

NERONI, R. de C. Amarelos da videira: identificação e análise filogenética dos fitoplasmas, transmissão dos agentes causais e otimização da diagnose. 2009. 96 f. Tese (Doutorado em Fitopatologia) Escola Superior de Agricultura Luiz de Queiroz, Universidade de São Paulo, Piracicaba, 2009.

NICKEL, O.; FAJARDO, T.V.M.; ARAGÃO, F.J.L.; CHAGAS, C.M.; KUHN, G.B. Detection and coat protein gene characterization of an isolate of Grapevine virus $B$ from corky bark-affected grapevines in Southern Brazil. Fitopatologia Brasileira, Brasília, DF, v.27, n.3, p.279-284, 2002.

OLIVER, J.E.; FUCHS, M. Tolerance and resistance to viruses and their vectors in Vitis sp.: A virologist's perspective of the literature. American Journal of Enology and Viticulture, Davis, v.62, n.4, p.438451, 2011.

OSMAN, F.; HODZIC, E.; OMANSKA-KLUSEK, A.; OLINEKA, T.; ROWHANI, A. Development and validation of a multiplex quantitative PCR assay for the rapid detection of Grapevine virus $A, B$ and $D$. Journal of Virological Methods, Amsterdam, v.194, n.1-2, p.138-145, 2013.

PANATTONI, A.; TRIOLO, E. Susceptibility of grapevine viruses to thermotherapy on in vitro collection of Kober 5BB. Scientia Horticulturae, Amsterdam, v.125, n.1, p.63-67, 2010.

PEREIRA, A. C. B. Proteína capsidial do Rupestris stem pitting-associated virus: sequenciamento do gene, expressão em Escherichia coli, purificação e produção de anti-soro policlonal. 2008. $66 \mathrm{f}$. Dissertação (Mestrado em Fitopatologia) - Instituto de Biociências, Letras e Ciências Exatas de São José do Rio Preto, Universidade Estadual Paulista, São José do Rio Preto, 2008.

PERRY, K.L.; MCLANE, H.; HYDER, M.Z.; DANGL, G.S.; THOMPSON, J.R.; FUCHS, M.F. Grapevine red blotch-associated virus is present in free-living Vitis spp. proximal to cultivated grapevines. Phytopathology, Saint Paul, v.106, n.6, p.663-670, 2016.
PICCOLO, S.L.; ALFONZO, A.; CONIGLIARO, G.; MOSCHETTI, G.; BURRUANO, S.; BARONE, A. A simple and rapid DNA extraction method from leaves of grapevine suitable for polymerase chain reaction analysis. African Journal of Biotechnology, Nairobi, v.11, n.45, p.10305-10309, 2012.

POOJARI, S.; ALABI, O.J.; FOFANOV, V.Y.; NAIDU, R.A. A leafhopper-transmissible DNA virus with novel evolutionary lineage in the family Geminiviridae implicated in grapevine redleaf disease by next-generation sequencing. PLoS One, San Francisco, v.8, p.e64194, 2013.

QIU, W.; AVERY, J.D.; LUNDEN, S. Characterization of a severe virus-like disease in Chardonnay grapevines in Missouri. Plant Health Progress, Saint Paul, nov. 2007. doi: 10.1094/PHP-20071119-01-BR

RADAELLI, P.; FAJARDO, T. V.M.; NICKEL, O.; EIRAS, M.; PIO-RIBEIRO, G. Variabilidade do gene da proteína capsidial de três espécies virais que infectam videiras no Brasil. Tropical Plant Pathology, Brasília, DF, v.34, n.5, p.297-305, 2009.

RENAULT-SPILMONT, A. S.; GRENAN, S.; BOURSIQUOT, J. M. Le deperissement de la Syrah, compte rendu de la reunion du group du travail du 23 Avril 2004. Progrès Agricole et Viticole, Montpellier, v.121, n.15/16, p.327-341, 2004.

RIEGER, T. New grapevine virus detected in California: Grapevine Pinot gris virus discussed at UCD FPS meeting. 2015. Disponível em: $<$ http:// www.winebusiness.com/news/?go=getArticle\&dat aid $=160912>$. Acesso em: 13 nov.2015.

ROHR DOS SANTOS, R.; ANDRADE, L. B.; BEDENDO, I. P.; DELAMARE, A. P.L.; ECHEVERRIGARAY, S. Detecção e caracterização molecular de fitoplasma do amarelo da videira no Rio Grande do Sul, Brasil. In: CONGRESSO BRASILEIRO DE VITICULTURA E ENOLOGIA, 13., 2015; CONGRESSO LATINO-AMERICANO DE VITICULTURA E ENOLOGIA, 15. 2015, Bento Gonçalves, RS. Resumos... Bento Gonçalves: Embrapa Uva e Vinho, 2015, p.309. 
ROOSSINCK，M. J.; MARTIN，D. P.; ROUMAGNAC, P.Plant virus metagenomics: Advances in virus discovery. Phytopathology, Saint Paul, v.105, n.6, p.716-727, 2015.

ROSA, C.; JIMENEZ, J.F.; MARGARIA, P.; ROWHANI, A. Symptomatology and effects of viruses associated with Rugose wood complex on the growth of four different rootstocks. American Journal of Enology and Viticulture, Davis, v.62, n.2, p.207-213, 2011.

ROUMI, V.; AFSHARIFAR, A.; SALDARELLI, P.; NIAZI, A.; MARTELLI, G.P.; IZADPANAH, K. Transient expression of artificial microRNAs confers resistance to Grapevine virus A in Nicotiana benthamiana. Journal of Plant Pathology, Bari, v.94, n.3, p.643-649, 2012.

RUIZ, V.S. Avances en viticultura en el mundo. Revista Brasileira de Fruticultura, Jaboticabal, v.33, n.1, p.131-143, 2011. Número especial.

RUMBOS, I.C.; AVGELIS, A.D. Roditis leaf discoloration - A new virus disease of grapevine: symptomatology and transmission to indicator plants. Journal of Phytopathology, Berlin, v.125, n.3, p.274-278, 1989.

SABANADZOVIC, S.; ABOU-GHANEM, N.; CASTELLANO, M.A.; DIGIARO, M.; MARTELLI, G.P. Grapevine fleck virus-like viruses in Vitis. Archives of Virology, New York, v.145, n.3, p.553565, 2000.

S A B A N A D Z O V I C, S .; GH A N E M SABANADZOVIC, N.A.; SALDARELLI, P.; MARTELLI, G.P. Complete nucleotide sequence and genome organization of Grapevine fleck virus. Journal of General Virology, London, v.82, n.8, p.2009-2015, 2001.

SALDARELLI, P.; GIAMPETRUZZI, A.; MORELLI, M.; MALOSSINI, U.; PIROLO, C.; BIANCHEDI, P.; GUALANDRI, V.Genetic variability of Grapevine Pinot gris virus and its association with Grapevine leaf mottling and deformation. Phytopathology, Saint Paul, v.105, n.4, p.555-563, 2015.
SKIADA, F. G.; MALIOGKA, V.I.; KATIS, N.I.; ELEFTHERIOU, E. P. Elimination of Grapevine rupestris stem pitting-associated virus (GRSPaV) from two Vitis vinifera cultivars by in vitro chemotherapy. European Journal of Plant Pathology, Dordrecht, v.135, n.2, p.407-414, 2013.

SUDARSHANA, M.R.; PERRY, K.L.; FUCHS, M.F. Grapevine red blotch-associated virus an emerging threat to the grapevine industry. Phytopathology, Saint Paul, v.105, n.7, p.1026-1032, 2015.

TERLIZZI, F.; RATTI, C.; FILIPPINI, G.; PISI, A.; CREDI, R. Detection and molecular characterization of Italian Grapevine rupestris stem pitting-associated virus isolates. Plant Pathology, Oxford, v.59, n.1, p.48-58, 2010.

THOMPSON, J. R.; FUCHS, M.; FISCHER, K. F.; PERRY, K. L. Macroarray detection of grapevine leafroll-associated viruses. Journal of Virological Methods, Amsterdam, v.183, n.2, p.161-169, 2012.

TSAI, C. W.; DAUGHERTY, M. P.; ALMEIDA, R. P.P.Seasonal dynamics and virus translocation of Grapevine leafroll-associated virus 3 in grapevine cultivars. Plant Pathology, Oxford, v.61, n.5, p.977985, 2012.

TSAI, C.W.; ROWHANI, A.; GOLINO, D.A.; DAANE, K.M.; ALMEIDA, R. P.P. Mealybug transmission of Grapevine leafroll viruses: an analysis of virus-vector specificity. Phytopathology, Saint Paul, v.100, n.8, p.830-834, 2010.

VEGA, A.; GUTIÉRREZ, R. A.; PEÑA-NEIRA, A.; CRAMER, G. R.; ARCE-JOHNSON, P. Compatible GLRaV-3 viral infections affect berry ripening decreasing sugar accumulation and anthocyanin biosynthesis in Vitis vinifera. Plant Molecular Biology, Dordrecht, v.77, n.3, p.261-274, 2011.

VILLATE, L.; FIEVET, V.; HANSE, B.; DELEMARRE, F.; PLANTARD, O.; ESMENJAUD, D.; VAN HELDEN, M. Spatial distribution of the dagger nematode Xiphinema index and its associated Grapevine fanleaf virus in French vineyard. Phytopathology, Saint Paul, v.98, n.8, p.942-948, 2008. 
WANG, Q.; CUELLAR, W. J.; RAJAMAKI, M. L.; HIRATA, Y.; VALKONEN, J. P.T. Combined thermotherapy and cryotherapy for efficient virus eradication: relation of virus distribution, subcellular changes, cell survival and viral RNA degradation in shoot tips. Molecular Plant Pathology, Malden, v.9, n.2, p.237-250, 2008.

XIAO, H.; KIM, W.S.; MENG, B. A highly effective and versatile technology for the isolation of RNAs from grapevines and other woody perennials for use in virus diagnostics. Virology Journal, London, v.12, n.171, p.1-15, 2015.
XU, K.; RIAZ, S.; RONCORONI, N.C.; JIN, Y.; HU, R.; ZHOU, R.; WALKER, M. A. Genetic and QTL analysis of resistance to Xiphinema index in a grapevine cross. Theoretical and Applied Genetics, Berlin, v.116, n.2, p.305-311, 2008.

ZHANG, Y.; SINGH, K.; KAUR, R.; QIU, W. P. Association of a novel DNA virus with the grapevine vein-clearing and vine decline syndrome. Phytopathology, Saint Paul, v.101, n.9, p.10811090, 2011. 